\title{
PARASITOLOGY
}

(Founded by G.H.F.Nuttall)

\author{
EDITED BY \\ D. KEILIN and P. TATE
}

IN CONJUNOTION WITH
A. BISHOP
E. HINDLE
F. J. BROWN
C. A. HOARE
P. A. BUXTON
G. LAPAGE

K. M. SMITH

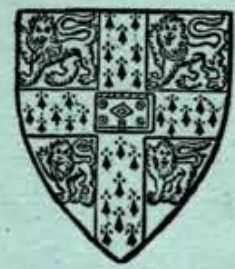

CAMBRIDGE UNIVERSITY PRESS LONDON: BENTLEY HOUSE, N.W.1 NEW YORK: 32 EAST 57TH STREET, 22 


\section{TYPICAL FLIES}

\section{A Photographic Atlas of Diptera}

By

\section{E. K. PEARCE}

Series $I$

Series $I I$

Series III

Each I6s. net

CAMBRIDGE
UNIVERSITY PRESS
MICHROME-

MICROSCOPIC STAINS

\section{Organic Reagents etc.}

Azocarmine Janus Green, B

Brilliant Cresyl Blue Lacmoid

Cedarwood Oil Leishman Stain

Field's Stain Martius Yellow

Giemsa Stain Rosolic Acid

Haematoxylin Trypan Red, etc.

Water analysis tablets

Stains and Reagents for Fluoresence Microscopy Biological Laboratory Apparatus

\section{EDWARD GURR, LTD.}

42 Upper Richmond Road, East Sheen, London, S.W.14

Telephone: Prospect $7606 \& 8051$ Cables: Micromlabs London

SERVICE, UNIFORM HIGH QUAITTY, RELIABIIITY, IMMIEDIATE DHETVERY

Notv ready: "Practical Manual of Medical and Biological Staining Techniques" (330 pages, price $26 s$. post free) by Edward Gurr, author "Microscopic Staining Techniques".

\title{
The Journal of
}

\section{General Microbiology}

\author{
Editors: B. C. J. G. KNIGHT and A. F. B. STANDFAST
}

The following is a representative selection from the 16 articles in Vol. 9, No. I.

Bergersen, F. J. A probable growth cycle in Bacillus megaterium.

Sugden, Brenda. The cultivation and metabolism of Oligotrich protozoa from the sheep's rumen.

Anderson, E. S. and Felix, A. Vi-type determining phages carried by Salmonella typhi.

Green, Margaret and Wilson, P. W. The utilization of nitrate nitrogen by the azotobacter.

Cowan, S. T. Micromethod for the Methyl Red Test.

Fulton, F and Isaacs, $\mathbf{A}$. Influenza virus multiplication in the chick chorio-allantoic membrane.

Gompels, Annette E. H. Antigenic relationships of swine influenza virus.

The subscription rate is 90 s, net per volume of 3 parts. Single parts 35 s. each, plus ...... postage. Two volumes will be issued each year. Orders should be sent to 